\title{
AS INTENSIDADES KAFKIANAS: REFLEXÕES ACERCA DO DESENCANTO JURÍDICO
}

\author{
Roberto José Covaia kosop ${ }^{1}$ \\ José Edmilson de Souza-Lima
}

\section{RESUMO:}

O presente artigo teve como intenção aproximar do campo jurídico as contribuições do escritor alemão Franz Kafka. Por intermédio de uma pesquisa bibliográficaa, analisou-se as concepções de identidade, mecanismos de dominação e burocratização do processo, todas inseridas no contexto kafkatino, trazendo ao Direito os pressupostos para a revaloração epistemológica. Assim, foi possível concluir que o desencanto jurídico em Kafka é também verificável no campo jurídico, uma vez que o mesmo é reflexo de fatores sociais. Logo, os distanciamentos entre sujeito o ordenamento podem se encurtar, uma vez que os fenômenos jurídicos sejam analisados sobre outros vieses, como, inclusive, pela Literatura.

Palavras-chave: Direito e Literatura; Desilusão Jurídica; Valorações Epistemológicas

\section{KAFKIAN INTENSITIES: REFLECTIONS ON LEGAL DISENCHANTMENT}

\begin{abstract}
:
This article intends to bring the contributions of the German writer Franz Kafka to the legal field. Through a bibliographical research, the conceptions of identity, mechanisms of domination and bureaucratization of the process, all inserted in the kafkian context, were analyzed, bringing to the Law the presuppositions for the epistemological revaluation. Thus, it was possible to conclude that the legal disenchantment in Kafka is also verifiable in the legal field, since it is a reflection of social factors. Thus, the distances between subject and order can be shortened, once legal phenomena are analyzed over other biases, such as Literature.
\end{abstract}

Keywords: Law and Literature; Legal disillusionment; Epistemological Values

\section{INTRODUÇÃO}

Os fenômenos jurídicos atuais requisitam de formações críticas e filosóficas que, muitas vezes, encontram-se adormecidas, para uma plural compreensão. O campo, como um

\footnotetext{
${ }^{1}$ Mestrando (bolsista CAPES) em Direito Empresarial e Cidadania pelo Centro Universitário Curitiba UNICURITIBA; Pós-Graduando em Filosofia e Teoria do Direito pela Pontifícia Universidade Católica de Minas Gerais - PUCMINAS e em Direito Contratual da Empresa pelo Centro Universitário Curitiba UNICURITIBA. Graduado em Direito pela mesma instituição; Atualmente é Vice-Presidente Regional Sul da Federação Nacional de Pós-Graduandos em Direito (FEPODI 2017/2019).

${ }^{2}$ Licenciado e Bacharel em Ciências Sociais pela Universidade Federal do Paraná, Mestre em Sociologia Política pela Universidade Federal de Santa Catarina, Doutor e Pós-Doutor em Meio Ambiente e Desenvolvimento pela Universidade Federal do Paraná. Entre 2014 e 2015 Coordenou o Núcleo de Pesquisa do Instituto Municipal de Administração Pública de Curitiba. Atualmente é pesquisador e docente do Mestrado em Direito do Centro Universitário Curitiba (UNICURITIBA) e do Programa de Pós-Graduação em Meio Ambiente e Desenvolvimento (PPGMADE) da Universidade Federal do Paraná (UFPR).
} 
fenômeno epistemológico, não pode ater-se a pensamentos unitários e retrógrados no tocante à auto-verificação e às portas interdisciplinares.

O estudo (e mergulho) no universo literário mundial, seja ele passado ou presente, fornece os indicativos necessários para o nascimento do Direito e as intensidades dos atos individuais capazes de fornecer as trilhas possíveis. O (re)pensar jurídico é palpável por intermédio de uma subversão de conceitos literários.

Logo, de forma a enriquecer o saber jurídico, o presente artigo tem a intenção de aproximar os pontos nucleares das obras Carta ao Pai, A Metamorfose, A Colônia Penal e $O$ Processo de Franz Kafka, sem esgotá-las, mas no intuito de demonstrar como o desencanto jurídico, em suas diversas formas de manifestação, são verificáveis em tais novelas.

O Direito e sua filosofia apresentam extensa magnitude ideológica capaz de englobar uma diversidade de problemáticas em uma constância crescente no presente momento histórico. Para haver uma conscientização e por fim um entendimento de seus objetos, a filosofia jurídica utiliza-se de métodos que realizam a tradução dos mais amplos fenômenos sociais para poder enfrentar os corriqueiros questionamentos do filósofo e pensador do direito.

O jogo de espelhos entre o mundo jurídico e o literário é capaz de demonstrar que na ficção há os ingredientes necessários para se ilustrar e avaliar o campo epistemológico do Direito. Assim, evidentemente que a metodologia adotada se baseou em uma análise bibliográfica, em especial, dos textos de Franz Kafka acima evidenciados, e os tendo como base para uma reflexão filosófica a partir de textos jurídicos.

Por fim, a partir da reflexão do sujeito kafkiano e suas potencialidades, pretende-se concluir que a desilusão para com o Direito se dá como um estágio natural de indignação que ruma para uma transformação estrutural do raciocínio jurídico, presando por sua evolução interdisciplinar e renovatória.

\section{REFLEXIVIDADE E DESILUSÃO}


Trazer o conceito de Modernidade, nada mais é que atrelar ao presente à capacidade de informação e liberdade. Uma sociedade livre de ilusões e capaz de escolher seus valores, por meio de novas culturas e sistematizações, é uma sociedade compromissada com o futuro.

A demonstração de uma variedade dentro das massas estabelece novas experiências de vida e, consequentemente, de dinâmicas sociais inéditas cheias do néctar necessário para a criação e auto-avaliação. Assim, natural que, antes do despertar, o desencanto seja uma parada obrigatória.

\begin{abstract}
O desencanto ocorre quando o homem se dá conta de que o mundo não tem um "sentido objetivo" e compreende que the compete criar uma "objetividade para o sentido"; além disso, a interligação entre o sentido e "realidade" também é responsabilidade sua. $\mathrm{O}$ desencanto convida a dois resultados: ou abrimos mão da ciência e passamos a admitir que todas as afirmações de que o conhecimento nos traz a "verdade" são fraudulentas, e que a vida é em si mesma "absurda" (niilismo negativo), ou aceitamos o desafio e passamos a encarar a ciência como um projeto humano. (MORRISON, 2006, p. 499)
\end{abstract}

A segunda opção exposta no enxerto acima de Morrison (2006) ilustra o objetivo que Ronald Dworkin (1978) trabalhou para perceber que o discurso jurídico estava ficando ultrapassado, necessitando, assim, propor uma teoria jurídica interpretativa calcada na interdisciplinaridade. ${ }^{3}$

Portanto, o Direito é não somente um instrumento, mas um campo epistemológico fértil a condensar os debates sociais. As temáticas ali trazidas necessitam, fundamentalmente, exercer uma prática interpretativa remodelada, já que o Direito não é estático ao encontrar-se dentro de cada sujeito capaz de novas valorações.

\begin{abstract}
O direito, antes de ser um exemplo de regras que se aplicam ora de maneira mecânica (easy cases), ora de maneira "refletida" nos casos difíceis, é a mais uma atitude interpretativa de uma comunidade que realiza a justiça. Antes do direito como justiça. Uma regra jurídica em todos os casos faz sentido porque ela corresponde à satisfação de um interesse material, a um valor, a um fim ou a um princípio. A aplicação de toda regra a uma situação concreta não se faz jamais de maneira irrefletida. (BILLIER; MARYOLI, 2005, p. 421-422)
\end{abstract}

\footnotetext{
${ }^{3}$ A representação do Direito a partir de uma visão jurídico-tecnicista, por mais que indispensável à criação de uma personalidade dogmática, não pode se perpetuar como o único caminho que o jurista deve trilhar. Muito pelo contrário. As novas tendências interpretativas ressaltam a possibilidade de abordagem dos questionamentos legais a partir de classificações e modelos de demais ciências e manifestações coletivas. Desta forma, tem-se que "a interdisciplinaridade não é uma simples técnica, mas uma postura, um modo de pensar e agir, é um exercício diário de raciocínio que ultrapassa os bancos escolares para interagir com o mundo complexo. Significa dizer que embora as unidades curriculares (disciplinas) sejam ministradas separadamente, devem interagir umas com as outras e com outras áreas do conhecimento, buscando, desta forma, explorar caminhos adequados a uma formação crítica, integral e transformadora." (ALVES, 2006, p. 103).
} 
O enfoque hermenêutico que Dworkin (1978) atribui aos seus estudos e a devida interpretação do Direito surgiu do desencanto e da insatisfação que o mesmo obtinha com a corrente jurídica predominante: o positivismo jurídico ${ }^{4}$. A formação e a função da base jurídica de uma sociedade moderna são indagações complicadas de obter uma resposta concreta, isto porque a camada principiológica é mutável e complexa.

O desenvolvimento jurídico é uma narrativa constante, de altos e baixos.

Para facilitar nosso entendimento da interpretação jurídica ou judicial, podemos usar uma analogia com a interpretação da literatura. Vários objetos estão envolvidos na crítica de um romance: tema, enredo, nível de coerência, caracterização. Dworkin diz que os críticos juristas precisam empregar critérios semelhantes ao refletirem sobre o que é o direito e de que modo se desenvolve. (MORRISON, 2006, p. 518)

A interdisciplinaridade entre Direito e Literatura é um ato essencial à interpretação do ordenamento moderno e da filosofia do Direito como um todo, tal como Dworkin se preocupou. Os literatas se confundem com os juristas ao criticarem as instituições e as atividades do Direito. Tudo com fundamentação e receios, para demonstrar um desencanto sadio e capaz de semear a disputa metodológica.

Não há como negar o fato de que a Filosofia está mesclada ao desenvolvimento das tensões entre os próprios anseios, a observação e a ação humana. A reflexão constante permite que haja o ato de repensar e revisar o que já estava concretizado. Tal proposta é deveras humanista, no sentido de que a reflexão seja favorável ao desenvolvimento do indivíduo e fortalecimento da filosofia, consequentemente, do Direito. A filosofia jurídica representa o potencial libertador, por meio do pensamento e da abertura às influências externas e fuga do isolamento dogmático.

Por isso, a filosofia está fora de moda, foi expulsa, é considerada correntemente, mesmo entre intelectuais, assunto que causa estranheza. Aliás, intelectuais se tornaram, na era da razão técnica, também fruto do positivismo, meros especialistas em assuntos afunilados, agindo e pensando sob cones de normas tecnicamente relevantes. (BITTAR, DE ALMEIDA, 2015, p. 9).

\footnotetext{
${ }^{4}$ Mesmo que o campo jurídico tenha obtido uma maior influência do que o positivismo jurídico de Hans Kelsen, importante estabelecer que as bases de tal pensamento provieram do Positivismo de Augusto Comte (17931857). Uma das grandes correntes filosóficos, em conjunto ao jusnaturalismo, que limita o objeto de conhecimento e estudo, versando os próprios julgamentos de valor ao direito positivo, ou seja, ao direito posto. O vocábulo "positivismo" insere a tendência de análise do objeto como um fato exterior a seu examinador, tentando descrevê-lo ou explicá-lo objetivamente partindo simplesmente de uma observação. "O pressuposto de todo positivismo é que existe uma instância do fato objetivo, e que a ciência pode explicá-la" (ALLAND; RIALS; 2012, p. 1361).
} 
A desmobilização da unidade que o positivismo criou, incomoda e desestabiliza as estruturas até então estáveis de pensamento. “O homem pós-moderno vive o paradoxo do adensamento da opressão e da fragilidade pessoal" (BITTAR, DE ALMEIDA, 2015, p. 11), pois as ciências que dele provêm, também sentem esta falha estrutural, que pode levar a perda das hegemonias. O jurista e o intérprete legal devem abraçar a mudança como uma velha amiga, na condição de conservar o que lhes cabe e ainda, atualizar o necessário a ensinar novas gerações.

Assim, entende-se que o desencanto é uma fase importante para se aceitar os desafios inéditos de uma era moderna e, neste sentido, a Literatura projeta-se como outra forma de expressão de tais ideais. Não há como tratar de desilusão sem que seja feita uma reserva a um dos maiores escritores do século XX, Franz Kafka (1883-1924). Nascido em Praga, na até então Tchecoslováquia, era filho de um pequeno comerciante da classe média. Motivo este que ainda criança, obteve um contato com diversas culturas.

Em 18 de Julho de 1906, Kafka colou grau, na qualidade de Doutor das Leis, prestando assim durante um ano, serviço obrigatório e não remunerado em um escritório que atendia não somente questões cíveis, mas como também criminais. No período entre o trabalho e o descanso que o autor começara a se desenvolver, analisando assim a situação que presenciara dos menos favorecidos que não conseguiam obter o devido acesso à justiça. Assim, criou seus heróis. Personagens estes desamparados que jamais conseguem encontrar solução legal para os seus problemas. Transpondo a figura do Estado como um ente maléfico que, por meio do Direito, abre seus tentáculos a fim de obstruir o caminho rumo à coisa julgada.

O conflito ético que se observa nas obras de Kafka é apresentado como um erro de ligação entre os polos trifásicos de uma relação jurídica: o indivíduo errante, o mundo real à sua volta e a construção de uma figura terceira, o Estado.

\footnotetext{
A entrada em cena da lei é assim preparada por uma série de mediações interpessoais que traduzem antes sua virtude libertadora. Solidamente ancorada na estrutura fiduciária das trocas intersubjetivas, a começar pela partilha de uma linguagem comum, instituição de todas as instituições, uma tal lei poderá pretender assar, com sucesso, pelo teste do critério da moralidade abstrata; ela será generalizável e até mesmo universalizável: longe de ser a decisão arbitrária e terrível de um "tu" tirânico imposta a um ser incapaz de protestar com o seu "eu", ela se presta ao jogo da universalização, de modo que o "tu" que a profere submete-se a ela como um outro, como qualquer outro. (OST, 2007, p. 391).
} 
A personalidade conturbada e reprimida de Kafka foi um dos pontos centrais para a exteriorização de suas potencialidades literárias e filosóficas. O erro na lógica ética universal kafkiana, nada mais é do que um produto de seus ressentimentos familiares.

\section{O ÍNTIMO E A (IN)VERDADE}

Em Carta ao Pai (1919), Kafka que estava ressentido devido a recepção fria de seu pai após o anúncio do noivado, redigiu ao seu genitor uma carta com mais de cem páginas, com intenção de desabafo. Uma obra intimista, mas muito reveladora, no sentido da origem das angústias do escritor tcheco.

\footnotetext{
Minha vaidade, minha ambição até sofriam com a acolhida, aos poucos famosa entre nós, que dedicavas a meus livros: Coloca em cima do criado mudo!" (na maior parte das vezes jogava cartas quando vinha um livro), mas no fundo eu me sentia bem apesar de tudo, não apenas por causa da maldade que se insurgia, não apenas por causa da alegria pela nova confirmação do modo como eu concebia a nossa relação, porém, bem na origem, porque aquela fórmula soava para mim mais ou menos como: "Agora tu estás livre!". Naturalmente isso era um engano, eu não estava ou, na melhor das hipóteses, ainda não estava livre. Minha atividade de escritor tratava de ti, nela eu apenas me queixava daquilo que não podia me queixar junto ao teu peito. Era uma despedida de ti, intencionalmente prolongada, com a peculiaridade de que ela, apesar de imposta por ti, corria na direção que eu determinava. Mas como tudo isso era pouco! (KAFKA, 2007, p. 69)
}

Nesta emblemática obra, Kafka representa seu pai como uma figura tirânica e excludente. Mesmo sendo um transmissor da lei interna da família, o titã falha em produzir no seu filho qualquer senso de justiça ou segurança. E assim, semeia a desilusão que o acompanharia durante toda sua trajetória de vida. Evidencia-se uma característica marcante em todas as obras de Kafka: a destruição do subjetivismo e a desestruturação valorativa do indivíduo perante uma figura maior, tida como monstruosa.

O casamento é, por certo, a garantia da mais nítida autoliberação e independência. Eu teria uma família, o máximo que em minha opinião pode ser alcançado, ou seja, o máximo que também tu alcançastes; eu estaria à tua altura e todas as velhas e eternamente novas vergonhas e tiranias passariam a ser apenas história. Com certeza seria fabuloso, mas é justamente aí que está o problema. E, demais, tanto assim não se pode alcançar. É como se alguém estivesse aprisionado e estivesse não apenas a intenção de fugir, o que talvez fosse alcançável, mas também e na verdade ao mesmo tempo, a de transformar reformando, para o uso próprio, a prisão num castelo de prazeres. (KAFKA, 2007, p. 89) 
Não obstante, como o próprio autor sempre afirmava, tentar obter conclusões a partir de seus textos é uma tarefa hercúlea. Suas obras merecem certo esmero no entendimento e dedicação nos atos reflexivos, pois as críticas e reviravoltas são imensas. Ninguém conseguiu descrever a personalidade ambígua de Kafka melhor que ele próprio. Marcado pelo conflito interno e pelo pensamento bilateral gostava de produzir estrofes e brincar com a dicotomia.

Ele é um cidadão da Terra, livre e protegido, pois está metido numa corrente comprida o suficiente para lhe deixar livres todos os espaços terrenos e, no entanto, comprida apenas o suficiente para que nada além dos limites da Terra possa alcançalo. Mas ao mesmo tempo ele é também um cidadão do Céu, livre e protegido, pois ele está metido numa corrente celeste concebida de modo semelhante à outra. Se ele quer estar na Terra, estrangula-o a coleira celeste, se ele quer ir para o Céu, estrangula-o a da Terra. E, não obstante, ele tem todas as possibilidades e sente isso; sim, ele recusa-se até mesmo a atribuir o todo a um erro no primeiro aprisionamento. (HARJES, 2013, p. 32-33)

Ao fim de Carta ao Pai, tem-se presente uma famosa confissão de que muitas das angústias e dos desânimos são produtos da sua própria consciência e, conforme o tempo passou, nem o próprio mais conseguia distinguir a realidade da ficção.

Naturalmente as coisas não se encaixam tão bem na realidade como as provas contidas na minha carta, pois a vida é mais do que um jogo de paciência; mas com a correção que resulta dessa réplica, uma correção que não posso nem quero discutir nos detalhes, alcançou-se a meu ver algo tão aproximado da verdade, que isso pode nos tranquilizar um pouco e tornar a vida e a morte mais fáceis para ambos. (KAFKA, 2007, p. 96)

Desta forma, a regra que Kafka elaborou para a transcrição dos meandros jurídicos em seus personagens, ao fim se aplicou à própria persona do escritor. $\mathrm{O}$ autoflagelo, ou como ele mesmo afirmava, a auto acusação, era pertinente para o Direito como um modo de pensar novos métodos de produção epistemológica.

Assim a auto acusação não tarda em preencher o vazio, Kafka não deixando a mais
ninguém exceto ele a tarefa de acusa-lo, ele que reconhecia ser criador somente na
arte de torturar-se a si mesmo. Donde a multiplicação, em seus textos de processos
sem delito e de execuções sem julgamento; donde as acusações tão desprovidas de
provas materiais quanto irrefutáveis diante do tribunal interior no qual, sob
diferentes máscaras, Kafka exerce simultaneamente os papéis de promotor, de
acusado, de testemunha e de juiz. (OST, 2007, p. 411)

A partir de tais pressupostos, tem-se claro o por quê de Kafka ser considerado um literata do absurdo (corrente também composta por Sartre, Camus e Beckett), apresentando 
contextos irracionais nos quais estão inseridos sujeitos desnudos de preconcepções jurídicas. O império do Direito presente no século XX é visivelmente retratado nos personagens e nas obras deste misterioso autor.

\section{TRANSFORMAÇÕES E METAMORFOSE}

Com este regramento em mente, passa a ser viável a devida interpretação de sua primeira novela escrita em 1912 chamada de A Metamorfose. Tal obra é contextualizada como um reflexo da estrutura bilateral entre o indivíduo e o social; a vítima do autor e portanto, a dignidade da pessoa humana e seus desmembramentos.

O início do conto é icônico e referenciado na literatura universal: "Quando, certa manhã, Gregório Samsa despertou, depois de um sono intranquilo, achou-se em sua cama convertido em um monstruoso inseto" (KAFKA, 1970, p. 168). Da humanidade à animalidade, acompanhamos a tragicomédia de um caixeiro viajante, o Sr. Gregor Samsa, que um dia acorda e se vê metamorfoseado em um inseto não especificado. Neste ponto e pelo próprio título, percebe-se que Kafka não se utiliza de Metáforas, mas sim de Metamorfoses. Ou seja, o escritor vira as costas às dissimulações e desencontros que produzem as metáforas, para propor algo experimental. Uma mudança e consequentemente, uma evolução de narrativa e dos parâmetros para se analisar os direitos individuais.

A preocupação do personagem não está em sua aparência, que acaba sendo um grande choque aos familiares, mas a possibilidade de faltar ao trabalho e assim perder a remuneração do dia. Ao abrir a porta de seu quarto, a reação de cada ente familiar fora de espanto e desprezo. De seu pai que o enxotava, até sua mãe que desmaiara com a condição de animalidade de seu filho. A constituição desta mudança acaba por comprovar o que Kafka experimentara.

Dar uma chance a uma verdade possível arriscando a experiência última da transformação das coisas segundo designação do sentido próprio: contar o que acontece quando realmente alguém vira cão, inseto, ou, ao contrário, quando o macaco se torna realmente sabido ou o cão põe-se a fazer investigações. (OST, 2007, p. 431-432)

Com o passar do conto, Gregor vai tomando conhecimento das suas modificações, adquirindo assim uma restrição ao senso de liberdade, pois havia receio em sair da residência 
e ser motivo de chacota pelos populares. Sua família passa a trata-lo como um animal, confabulando formas e maneiras de como prosseguir e principalmente arranjar uma nova fonte de renda, pois Gregor era o pilar que sustentava o núcleo familiar.

\begin{abstract}
Já no primeiro dia o pai expôs à mãe e à irmã a verdadeira situação econômica da família e as perspectivas que diante desta se abriam. De vez em quando levantava-se da mesa para procurar em sua pequena caixa de papéis - salva da falência cinco antes - algum documento ou livro de notas. Ouvia-se o ruído da complicada fechadura ao abrir-se e tornar a fechar-se, depois que o pai tirava o que tinha ido buscar. Estas explicações foram, de certo modo, a primeira notícia agradável que Gregório pode ouvir desde seu encerramento. Ele sempre acreditara que não restara nada a seu pai, absolutamente, do antigo negócio. (KAFKA, 1970, p. 187-188)
\end{abstract}

A metamorfose que o personagem principal sofrera, pode ser considerada como a mudança interna que um indivíduo passa no momento em que se encontra desempregado. A vergonha e humilhação pode ser tanta, que o sujeito sente-se dispensável e diferente. Estar desempregado temporariamente e, portanto, desamparado economicamente, atrai uma repulsa da família a ponto que o próprio protagonista se vê metamorfoseado.

A mãe de Gregor era a única integrante que mantivera um resquício de vínculo com o filho, mas não era autorizada a entrar no quarto em que o personagem estava enclausurado. Entretanto, contrariando o pai, a genitora de Gregor entra no quarto para propor ao filho a retirada dos móveis a fim de que o mesmo pudesse se locomover da melhor forma, devido sua dantesca nova forma.

Conquanto, a mãe desmaiou ao avistar o filho e assim, Gregor deixa o quarto, pois fora rejeitado pela única pessoa que ainda mantinha o vínculo com o meio social. De forma truculenta, o pai que já havia desistido de reconhecer naquela criatura, seu filho, acaba por tomar medidas drásticas.

Tinha enchido os seus bolsos com o conteúdo da fruteira que estava sobre o aparador, e atirava uma maçã atrás de outra, embora sem conseguir pelo momento acertar no alvo. As maçãs vermelhas rodavam pelo solo, como eletrizadas, tropeçando uma nas outras. Uma delas, atirada com mais habilidade, roçou a espádua de Gregório, mas deslizou por ela sem causar-lhe dano. Em troca, a seguinte, assestou-lhe um golpe certeiro, e, ainda tentando escapar-se, como se aquela intolerável dor pudesse desvanecer-se ao mudar de sítio, pareceu a Gregório que o cravaram onde estava, e permaneceu ali esparramado, perdendo a noção de quanto acontecia em torno. (KAFKA, 1970, p. 199)

Por fim, Gregor é trancado em seu quarto e esquecido por todos, pois estava claro que aquela figura a par da sociedade e desempregada não tinha as mínimas condições de fazer 
parte da normalidade. Contudo, a maçã em seu corpo apodrece completamente, inflamando as costas e libertando Gregor daquele corpo visceral. Tem-se morto sozinho e esquecido por todos.

Este conto inicial de Kafka consegue muito bem apresentar ao leitor o mundo surreal que o autor impõe aos seus heróis, mas sempre com um propósito maior. $\mathrm{O}$ discurso de $A$ Metamorfose é muito bem relacionado à visão dos Direitos Humanos legitimados no presente, principalmente a mobilidade da dignidade da pessoa humana contra as mazelas sociais.

A família de Gregor faz as vias da sociedade contemporânea, que ao invés de proporcionar um ambiente de possibilidades, traz ao desempregado/presidiário/inseto, uma forma hostil e impossível de recuperar a humanidade. Os móveis retirados do quarto, nada mais são do que as oportunidades de uma nova vida que deveria estar garantida pela família social. Entretanto, o coletivo acaba por aceitar as transformações, seja de homem livre a presidiário, empregado a desempregado, sujeito ao animal e, assim, não apresenta subsídios para a construção de uma nova vida. Legitima-se, portanto, uma ordem social excludente e seletiva.

\footnotetext{
A sociedade não só já é numerosa e concentrada, como muito diferenciada quanto aos tipos que a compõem: há os muito rico e muito pobre, muito cultos e muito ignorantes, os livres e os escravos, os cidadãos que participam dos negócios públicos formando uma minoria e a maioria excluída. Enfim, uma sociedade estratificada pelos privilégios de seus estratos, superpostos mais ou menos impermeáveis. Internamente, esta sociedade está em eterno conflito, de todos contra todos. (SCHNAID, 1998, p. 85-86)
}

Exatamente desta dicotomia que A Metamorfose consegue fazer um breve retrato. A eterna briga social entre o que é e o que não é aceitável como maioria, e principalmente, quais os parâmetros entre o comum e o bizarro. O conflito ideológico de Gregor e seus familiares estende-se ao visual, pois é o repúdio pelo diferente que acaba por excluí-lo do núcleo que amava. Por meio de uma ordem segregadora, o inseto é isolado de todos em um quarto.

\footnotetext{
Assim, o Direito se impõe como poder a partir de um discurso que funda e legitima uma ordem social de exclusão. Esse discurso - competente - cria verdades unas, ou seja, universos universalizados que, supostamente munidos de neutralidade, relega a marginalização qualquer outro discurso, porque desautorizado, e opera um adestramento da sociedade em uma realidade objetiva. (GRUBBA, 2011, p. 115)
}

Desta forma, a posição liberal de Kafka tem-se exposta, mesmo que em uma camada abaixo da simples primeira interpretação, mas é exatamente este o ponto chave de $A$ 
Metamorfose, uma crítica à ordem social de exclusão e consequentemente, ao Direito como forma de instrumentalizar a vontade de uma maioria à minoria excluída.

\footnotetext{
Nesta forma societária, a manutenção do statu quo só é possível graças às normas impostas pelo Estado, coercitivamente, acompanhadas de sanções severas para os infratores. O Direito é uma exigência da vida estatal: "ubi homo, ibi societas; ubi societas, ibi jus". (SCHNAID, 1998, p. 86)
}

Esta é uma das infelizes tendências da sociedade contemporânea que Kafka expunha e combatia: a diferença de aplicação de um direito aos indivíduos que diferem em razão do gênero ou condição social. Portanto, um breve conto literário, mas com extensas linhas de raciocínio e principalmente, de crítica à ordem social imposta e à ordem jurídica instrumentalizada. A intrínseca relação entre Direito e Literatura é vista em A Metamorfose, como uma severa crítica às dimensões e capacidades humanas de exclusão social e a infeliz legitimação jurídica de tal ato, ainda que de forma abstrata.

\section{MECANISMOS DE DOMINAÇÃO}

Em uma de suas novelas mais emblemáticas, Kafka apresenta um campo de trabalhos em uma ilha tropical, passando pela visita de um Explorador estrangeiro que ali permanece para analisar e aprender sobre o processo jurídico predominante.

A Colônia Penal demonstra de uma forma muito contundente e ilustrativa, um ambiente que a lei se perdeu por completo, sendo tratada de forma aleatória e imprevisível. O Explorador acompanha o Comandante durante a sessão de punição de um soldado insubordinado, que é submetido a uma máquina obsoleta que tem por finalidade marcar a sentença no corpo do condenando. Como uma forma de reafirmação do poder legal, tal máquina é a lembrança de uma forma de execução jurisdicionada pelo ex-comandante da colônia penal. Ao iniciar os preparativos para a Execução, o Explorador questiona o Comandante se houve algum processo de defesa e se antes de tudo, o indivíduo sabe que foi devidamente condenado.

\footnotetext{
- Mas ao menos sabe que foi condenado?

- Também não - disse o oficial sorrindo como se esperasse que lhe fizesse outra pergunta extraordinária.
} 
- Não - disse o explorador, e passou a mão pela fronte - então, o indivíduo também ignora como foi conduzida a sua defesa?

- Não lhe foi dada nenhuma oportunidade de defender-se. (KAFKA, 1970, p. 122)

A figura de juiz, fiscal e executor da pena se misturam e fundem em uma só pessoa, que arbitrariamente e de acordo com suas próprias vontades aplica a pena que achar devidamente cabível. Da mesma forma, Kafka analisa que o Poder Soberano exercendo uma força coercitiva e disciplinar acaba por agir fora dos parâmetros humanitários e modernos, sendo que a maior preocupação torna-se em manter o território como objeto da pena e não o indivíduo.

Fui designado juiz da colônia penal. Apesar de minha juventude. Porque eu era o
conselheiro do antigo comandante em todas as questões penais, e além disso
conheço o aparelho melhor que ninguém. Meu princípio fundamental é este: A culpa
é sempre indubitável. Talvez outros tribunais não sigam este princípio fundamental,
mas são multipessoais, e além disso dependem de outras câmaras superiores
(KAFKA, 1970, p. 122)

Evidente que a primeira crítica desta novela, encontra-se em que o Direito nada mais é que uma forma de exercer o Poder sobre outrem, e desta forma se somente um indivíduo sustenta mais de uma posição de ordem jurídica, acabará por eventualmente se deixar corromper pela própria Lei. A forma de gravar na carne a sentença de um condenado, muito bem demonstra a força imperativa do texto legal, que bem ou mal, estará marcado para sempre no corpo do sujeito. Uma imensa distinção entre a sadia absorção legal pelo entendimento epistemológico, do que o proposto no conto, onde há um suplício dos tempos modernos.

Em "Colônia Penal" Kafka propõe uma situação em que a lei é escrita nas pessoas como sentença, por meio de uma máquina que imprime na pele do condenado a lei através de agulhas que perfuram seu corpo e levam o sentenciado à morte. A lei está impressa, porém não se segue um processo que permita a defesa do condenado ou mesmo a ciência do crime que cometeu. A lei é aplicada fisicamente e o poder final apesar de estar na mão do carrasco, apresenta-se difuso e sem face, pois ele é exercido de forma autoritária por diversos funcionários públicos. Kafka aponta para uma mudança de paradigmas na aplicação dessa lei. (SALGADO, 2015)

A noção kafkiana de Direito e Estado se fundem em um tom diverso ao do indivíduo, permanecendo este a mercê da boa vontade de terceiros. Carece de seus princípios fundamentais, tais como a Igualdade e Liberdade, no instante em que o Estado perpetua sua vontade de uma forma coercitiva e oposicionista à sociedade democrática. O Direito entra 
como um instrumento cego e extremamente maleável para promover a dominação dos indivíduos. As garantias legais não mais existem em um ambiente que o formalismo e a coerção são a regra, pois a conduta social não consegue ser devidamente regulada pelas instituições. As básicas noções legais de coação e sansão se misturam, não podendo assim ao certo distinguir a Moral do Direito.

Para além da repulsa que a crueldade do suplício prova (e que fará o viajante fugir), não se sabe muito o que pensar. É que a condenação implícita dos métodos do oficial é acompanhada de uma espécie de nostalgia dos tempos antigos nos quais reinava a lei do ex-comandante: uma lei dura, certamente, mas justa e conhecida de todos. Uma lei partilhada, geradora de uma comunidade calorosa e viva que hoje dá lugar ao triste abandono dos valores e à incerteza das normas modernas. O êxtase dos condenados na sexta hora de seu suplício, no momento em que a escrita avançou bastante para que eles saibam onde está o direito, não é nesse ponto reveladora como sinal ou como promessa de sua reintegração no seio da comunidade? (OST, 2007, p. 435-436)

Tal preocupação é foco de filósofos do Direito que tentam delimitar quais os padrões dos elementos coercitivos estatais. O Poder Público naturalmente exerce o serviço jurídico, a promulgação de suas exigências, substituindo assim a vontade material do indivíduo, que por muitas vezes é abafado, em prol do bem comum.

$\mathrm{Na}$ realidade, não há como confundir coação e força, sendo aquela, como efetivamente é, a força disciplinadora, exercida nos limites legitimados pela tutela necessária de bens da convivência. Sanção e coação são duas noções distintas que estão uma para a outra, de certa forma, como o gênero está para a espécie. São múltiplas as sanções, ou seja, as medidas tendentes a assegurar a execução das regras de direito, desde a declaração da nulidade de um contrato ao protesto de uma letra de câmbio; desde o ressarcimento de perdas e danos sob forma de equivalente indenização até ao afastamento de funções públicas ou privadas (...) Ora, tais medidas, que podem ser preventivas, repressivas ou premiais, como o diz a Teoria Geral do Direito, podem contar ou não com a obediência e a execução espontânea dos obrigados. (REALE, 2013, p. 640)

O regramento jurídico é criticado por Kafka, não somente nesta sua obra, mas durante toda sua bibliografia, o Direito é objeto de análise mais especificamente no tocante ao crescimento da normatividade e até quanto isto é benéfico para a população.

O mesmo questionamento, porém de forma mais explícita e expositiva, foi realizado pelo filósofo Michel Foucault (2001). Este, como um verdadeiro antropólogo, resgata a concepção de Poder e suas variações e formas de aplicação, seja de maneira coercitiva ou subjetiva. O crescimento constante de uma forma de poder implícita é o nível que Foucault atribui ao controle social que se desenvolve nas menores camadas do coletivo. Cada esfera do 
poder emana Poder por meio de suas instituições, e assim serve como uma força reguladora da vida e das ações humanas. A Disciplina, com destaque aquela porvindoura de coerção jurídica, passa a ser a força motriz de sancionar o que é ou não legal. Mesma dinâmica usada pelo Rastelo, máquina primitiva da Colônia Penal que marcava a pele do condenado sem qualquer julgamento de valor ou mérito.

Este novo tipo de poder, que não pode mais ser transcrito nos termos da soberania, é uma das grandes invenções da sociedade burguesa. Ele foi um instrumento fundamental para a constituição do capitalismo industrial e do tipo de sociedade que lhe é correspondente; este poder não soberano, alheio à teoria da soberania, radicalmente heterogêneo, o poder disciplinar deveria ter causado o desaparecimento do grande edifício jurídico daquela teoria. (FOUCAULT, 2001, p. 188)

Os sistemas jurídicos por meio deste poder disciplinar são responsáveis pela criação das formas de soberania. Entretanto, Kafka e Foucault criticam que o Poder Público apropriando-se exclusivamente do Direito, acaba por fixar-se em mecanismos de coerção. Neste ponto, o literata ilustrou e o filósofo explicou:

\begin{abstract}
Mais rigorosamente: a partir do momento em que as coações disciplinares tinham que funcionar como mecanismos de dominação e, ao mesmo tempo, se camuflar enquanto exercício efetivo de poder, era preciso que a teoria da soberania estivesse presente no aparelho jurídico e fosse reativada pelos códigos. Temos, portanto, nas sociedades modernas, a partir do século XIX até hoje, por um lado uma legislação, um discurso e uma organização do direito público articulados em torno do princípio do corpo social e da delegação de poder: e por outro, um sistema minucioso de coerções disciplinares que garanta efetivamente a coesão deste mesmo corpo social. Ora, este sistema disciplinar não pode absolutamente ser transcrito no interior do direito que é, no entanto, o seu complemento necessário. (FOUCAULT, 2001, p. 189)
\end{abstract}

Foucault ainda alerta que é extremamente necessário que haja algum tipo de discurso mediador, pois "as normalizações disciplinares chocam-se cada vez mais frequentemente com os sistemas jurídicos da soberania: a incompatibilidade de umas com os outros é cada vez mais nítida" (FOUCAULT, 2001, p. 190). A repressão, portanto caso seja a regra e crie uma cultura de medo e imposição, os sujeitos, tanto infratores quanto juristas, irão se tornar, como muito bem elucidou Kafka (2007), uns aquéns da lei.

\title{
6 INDIVÍDUO CONTRA O ORDENAMENTO
}


Em $O$ Processo, Kafka extrapola o que já tinha demonstrado até então realizando assim uma crítica frontal à Lei e ao Procedimento Jurídico como um todo. Na situação da obra, tem-se apresentado ao leitor, Josef K., um indivíduo que em uma manhã é detido arbitrariamente, sem nenhuma explicação de quem e do por quê.

Ao longo de todo o romance, especula-se sobre uma Administração, uma Organização ou até mesmo uma Grande Organização. Mas nenhuma certeza é demonstrada, nem da instituição que administra seu procedimento e muito menos sobre a matéria processual. Josef K. reconhece que sua abdução trata-se de um processo judicial pois consegue vislumbrar algumas características do tal, pois ninguém explicitamente o informa.

Tratando ainda de repressão, $O$ Processo consegue o que até hoje nenhuma outra obra conseguiu: demonstrar que não somente o Direito Material é Repressor, o Direito Processual é uma arma feroz e de imenso calibre para subjugar um indivíduo leigo. A detenção apresentada no romance não implica na perda de liberdade ou em algum tipo de prisão física, pois $K$. pode permanecer em sua residência e frequentando seu trabalho normalmente, mesmo estando na posição de detido. $\mathrm{O}$ inspetor que realiza a detenção explica este procedimento nefasto, onde K. mantém a liberdade física, mas torna-se enclausurado: “o senhor me entendeu mal. É claro que o senhor está detido, mas isso não deve impedi-lo de cumprir os deveres de sua profissão. Aliás, o senhor também não deve ser perturbado com seu modo de vida habitual" (KAFKA, 2006, p. 29).

A situação expressa, onde a burocratização judicial encontra seu ápice, é de um tom extremamente opressor, em que o acusado é obrigado a adivinhar o por quê da acusação e de humilhação porvindoura.

No romance "O Processo" a burocracia é um dos personagens principais. Os policiais, juízes e outros funcionários que lidam com o direito são retratados como pessoas que seguem regras e protocolos, porém que não sabem de onde vêm essas ordens. Eles somente sabem que estas leis devem ser cumpridas. A hierarquia se alonga de determinada maneira, que a pessoa que ordena uma determinada ação dificilmente pode ser identificada (SALGADO, 2015).

Logo, K. parte em uma odisseia para descobrir e trazer à luz sua situação legal, participando de inquéritos e investigações, sem mesmo saber o objeto que o Tribunal procurara. O personagem, portanto, começa a desconfiar das próprias atitudes e por assim, o processo "judicial" acaba por ganhar a característica de universal e capaz de reger a vida de $\mathrm{K}$., pois o mesmo reconhece àquela Lei como a verdade. "O senhor pode objetar que sequer 
se trata de um processo, e terá toda a razão, pois apenas se tratará de um processo se eu o reconhecer como tal" (KAFKA, 2006, p. 58).

Mesmo clamando pela publicidade e por informações, a culpa começa a se espalhar como uma doença psicológica em K., que passa a não somente ser um acusado, mas se autoacusando. Por assim, Kafka demonstra as mazelas que um processo judicial mal formulado, burocratizado e abusivo tem sobre o indivíduo, independentemente de seu grau escolar e conhecimento jurídico.

[...] há primeiro, o movimento mais aparente, o da acusação exterior por um poder malévolo (a Organização, a Administração, o Tribunal...), que se choca contra os protestos de inocência, incessantemente reiterados, de Josef. K.; há, a seguir, o motivo oposto da auto-acusação, alusivo no início, mais explícito no final; a ele se sobrepõe - terceiro tema - a tomada de consciência das pequenas faltas realmente cometidas por K. ao longo dos doze meses da ação judicial; há, enfim, o movimento de fundo da narrativa que se inscreve num registro quase inconsciente, e que mostra a lenta metamorfose, tanto física quanto psíquica, do inocente em culpado. (OST, 2007, p. 446-447)

K. passa a frequentar voluntariamente o Tribunal, pois além de não existir confiança com o órgão administrador do processo, o personagem passa a se tornar obsessivo com a própria figura do âmbito jurídico. Como se fosse um mundo a parte do real, K. percebe que não há claramente um acesso ao tribunal. O imóvel labiríntico e dantesco, é uma alusão ao próprio processo, que como se houvesse vida própria, caminha por veredas independentes de acompanhamento por advogados ou cartorários.

Era um corredor longo, do qual portas de madeira crua levavam para as repartições individuais do sótão. Embora não existisse nenhuma fonte de luz nas proximidades, não estava de todo escuro, pois algumas das repartições tinham, na parte que dava para o corredor, em vez de paredes de tábuas homogêneas, grades de madeira que alcançavam até o teto, pelas quais passava alguma luz e entre as quais podiam ser vistos alguns funcionários, que estavam às mesas que ocupavam ou que acabavam de chegar junto às grades e observavam, pelas frestas, as pessoas no corredor. Provavelmente por ser domingo, havia poucas pessoas no corredor. Elas davam uma impressão de extrema humildade. A distancias praticadas regulares umas das outras, estavam sentadas em duas filas de bancos de madeira bem longos, que haviam sido colocados em ambos os lados do corredor. Todos estavam vestidos de modo negligente, ainda que a maior parte deles, pela expressão do rosto, pela postura, pela barba e por muitos pequenos detalhes dos quais mal se podia dar conta, pertencesse às classes mais altas. Uma vez que não havia cabides de roupas, eles haviam depositado seus chapéus, provavelmente um seguindo o exemplo do outro, embaixo do banco. Quando aqueles que estavam sentados mais próximos à porta vislumbravam K. e o oficial de justiça, levantaram-se para cumprimenta-los, acreditaram que deviam fazer o mesmo, de modo que todos se levantavam quando os dois passavam. Eles jamais se levantavam a ponto de ficarem totalmente eretos; 
as costas ficavam curvadas, os joelhos dobrados; e eles ficavam parados como mendigos na rua. (KAFKA, 2006, p. 82)

Assim, o espaço físico que é caracterizado de uma forma fria e estruturada para demonstrar poder capaz de subjugar o indivíduo, desintegra, por si só, a característica fundamental da lei de ser uma criação com fins apaziguadores. Isto posto, trata-se de um verdadeiro retrocesso à opressão e violência psicológica ao indivíduo. Em O Processo, a culpa e a dúvida são as imposições capazes de transformar um homem, tal que a solidão e divergência são as potencialidades metamórficas de $A$ Metamorfose. K. passa por alterações perceptíveis na narrativa, onde o leitor acompanha a desventura, conjuntamente com os personagens que rodeiam o protagonista kafkiano.

[...] - tú estás transformado, sempre tiveste uma capacidade de visão tão correta, e justo agora ela te abandona? Por acaso queres perder o processo? Sabes o que isso significa? Significa que simplesmente será riscado do mapa. E que toda a parentela será levada juto, ou pelo menos humilhada até o chão. Josef, concentra-te um pouco. Tua indiferença me põe fora de juízo. Quando a gente te vê assim, quase sente vontade de dar crédito ao provérbio que diz: "ter um processo desses já significa perde-lo". (KAFKA, 2006, p. 119)

Em um procedimento que não existe publicidade alguma dos atos, os defensores são desconhecidos e desnecessários e os documentos permaneçam inacessíveis à defesa, torna-se uma questão de tempo que o acusado perca qualquer noção de justiça e de realidade, isolandose do âmbito social. O processo representado por Kafka é não somente um processo de repressão e opressão, como um meio de exclusão social. Judicializar e burocratizar uma questão, sem dá-la a devida publicidade é uma forma de detenção maior do que qualquer prisão de segurança máxima. A despersonificação do indivíduo vai se tornando evidente com o passar dos fragmentados expostos por Kafka da triste história de seu impotente personagem.

A triangulação do sistema judiciário, onde se tem muito bem definidas as figuras do Autor, Réu e Juiz, é completamente ignorada por Kafka. O Processo acaba por realçar a importância deste estabelecimento. Na obra literária, a demonstração de uma bilateralidade somente, onde em nenhum momento têm-se certa a figura do Acusador, e somente o Réu é um polo estabelecido, a culpa predomina e as relações pessoais inexistem. Logo, correta é a afirmação que $O$ Processo critica veemente à burocratização do Poder Judiciário, como realizada uma Ode à Publicidade. 
Durante toda a fragmentação kafkiana, é possível considerar o processo não somente como uma manifestação de indignação, mas o estabelecimento do Processo Jurídico como uma essência, um elo essencial para manter relações de poder e opressão. O tempo é usado como uma arma do processo, a forma mais eficaz de coação e apreensão do indivíduo.

Em Kafka, o dramático é, ao contrário, a interrupção do tempo o adiamento que, de alguma maneira, para o tempo. O tempo é interrompido. Num certo sentido, o círculo do tempo é (inter)rompido. Em (e para) Kafka a vida é tão intensamente enredada que seu curso natural é o da suspensão e da surpresa (ao menos, para nós leitores). Uma ruptura no círculo do tempo, na sua concepção filosófica vulgar (segundo Heidegger), sugere uma outra (menos vulgar) concepção de tempo, a qual considera, não mais um círculo, mais sim um salto. A surpresa nada mais é do que um salto. (CHUEIRI, 2008, p. 75)

A autoridade que o Processo exerce sobre os indivíduos é a justificação da aplicação aparentemente aleatória que Kafka demonstra. A Lei por não ser exteriorizada de forma pública, paradoxalmente faz com que os indivíduos a conheçam e tentem a entender, por meio da exclusão. À procura do acesso, K. jamais descobre quem é seu real Acusador ou qual o motivo ensejador da demanda judicial, mas acaba tomando conta do seu lugar em uma sociedade imperativa de Direito. Uma posição de submissão e por fim, de aceitação.

Mesmo com a assistência temporária de um advogado ou por intermédio de suas próprias diligências, K. assume o papel de culpado e presidiário, mesmo sem ter passado um dia sequer em qualquer instituição de correção ou prisão. Espera, portanto a execução, como se esperasse uma fase normal de transição em sua vida.

A transformação de Gregor Samsa é irmã da que K. sofre. A diferença somente se encontra no tempo literário. Enquanto a primeira é o marcador do início de A Metamorfose e todas as mudanças são em decorrência desta, K. passa por sua metamorfose, mesmo que simbólica, na frase derradeira de $O$ Processo.

\footnotetext{
Mas as mãos de um dos senhores se colocaram à garganta de K., enquanto o outro cravava a faca profundamente em seu coração, virando-a duas vezes. Com olhos esbugalhados, K. ainda viu como os dois senhores, próximos a seu rosto, apoiados face a face observavam a decisão:

- Como um cão! ele disse. Era como se a vergonha devesse sobreviver a ele. (KAFKA, 2006, p. 262)
}

A autoacusação pela qual K. se faz passar, conjuntamente com a arbitrariedade processual, produzem uma metamorfose no protagonista que não vê outra alternativa senão se entregar à execução. Entretanto, a mesma passa a ser vista não como uma imposição jurídica, 
mas como um verdadeiro sacrifício. K., então, descobre ao fim, que a solidão e a burocratização judicial, o excluíram da sociedade e por nenhum momento ele esteve acompanhado. Para todos, seja para a Administração ou para seus amigos e parentes, no momento em que fora instaurado de ofício um procedimento judicial, K. não passava de um mero animal, um pífio cachorro.

\section{CONCLUSÃO}

As invenções de Kafka obtiveram uma enorme influência na construção jurídica do século $\mathrm{XX}$, em especial, o impacto que suas narrativas tiveram ao antecipar os principais dilemas que o campo jurídico contemporâneo enfrenta. Ao repensar os paradoxos jurídicos, por intermédio da complexidade de seus personagens, Kafka demonstrou como o desencanto jurídico é um ponto de partida para promover novas análises dos signos e das figuras que compõe este variado meio social.

Respondendo à provocação inicial, o autor, ao observar os desdobramentos dos sujeitos perante desafios da teoria do Direito contemporâneo, fixam um marco inicial que possa revalidar a discussão acerca da (im)possibilidade de acessar o ordenamento jurídico eficaz. As inconsistências científicas, as arbitrariedades do positivismo e a fragilidade da episteme jurídica são evidenciadas nos enxertos acima demonstrados.

Entendendo que o presente estudo não se dignou a esgotar a análise das obras do autor, tem-se claro a necessidade de continuidade no estudo kafkiano, uma vez que o homem esteja diante de uma entidade que emane poder, sempre haverá formas e meios de manifestar a autoridade, seja através de um sistema de regras e convenções jurídicas aceitas ou de formas arbitrárias e investidas de intenções maléficas à capacidade individual. A falta de identidade verificada em Carta ao Pai, a desumanização do sujeito entendida na Metamorfose, o sistema imperativo na Colônia Penal e a burocratização esquizofrênica do Processo são tópicos que permitem a desconstrução e a reinterpretação do campo jurídico a partir de seus paradigmas.

Por fim, possível concluir que o distanciamento que Kafka denuncia existente entre os que obedecem à lei e aqueles que a criam e a estudam pode diminuir com a presente intenção, ou seja, transcender as barreias valorativas jurídicas a fim de que pressupostos interdisciplinares estejam presentes para refundar o campo epistemológico jurídico, tal como 
as incursões de Direito e Literatura. Não obstante, capaz afirmar que a solução de Kafka está em Kafka.

\section{REFERÊNCIAS}

ALLAND, Denis; RIALS, Stéphane. Dicionário da Cultura Jurídica. São Paulo: Martins Fontes, 2012.

ALVES, Elizete Lanzoni. A Docência e a Interdisciplinaridade: um desafio pedagógico. In: COLAÇO, Thais Luzia (Org.). Aprendendo a Ensinar Direito o Direito. Florianópolis: $\mathrm{OAB} / \mathrm{SC}, 2006$.

BILLIER, Jean-Cassien; MARYOLI, Aglaé. História da Filosofia do Direito. Barueri: Manole, 2005.

BITTAR, E. C. B.; DE ALMEIDA, G. A. Curso de Filosofia do Direito. 11 ed. São Paulo: Atlas, 2015.

CHUEIRI, Vera Karam de. Kafka, kavka, K: do nebuloso ao que se revela como surpresa. In: TRINDADE, A.K, GUBERT, R.M., NETO, A.C. Direito \& Literatura: ensaios críticos. Porto Alegre: Livraria do Advogado, 2008.

DWORKIN, Ronald. Taking Rights Seriously. Cambridge, Mass: Harvard University, 1978.

FOUCAULT, Michel. Microfísica do Poder. Santa Ifigênia: Graal, 2001

GRUBBA, Leilane Serratine; OLIVO, Mikhail Vieira Cancelier de. Kafka: A metamorfose para os direito humanos In: Direito e Práxis, vol. 03, n. 02, 2011, p. 115. Disponivel em: < http://www.e-publicacoes.uerj.br/index.php/revistaceaju/article/view/2099> Acesso em: 13.mai.2017.

HARJES, Stefanie. Meu Kafka. São Paulo: Cosac Naify, 2013.

KAFKA, Franz. . A Colônia Penal e outros contos. Rio de Janeiro: Ediouro, 1970

Carta ao Pai. Porto Alegre: L\&PM, 2007.

O Processo. Porto Alegre: L\&PM, 2006.

MORRISON, Wayne. Filosofia do Direito: dos gregos aos pós-modernismo. São Paulo: Martins Fontes, 2006

OST, François. Contar a Lei: As Fontes do Imaginário Jurídico. São Leopoldo: Unisinos, 2007. 
REALE, Miguel. Filosofia do Direito. 20. ed. São Paulo: Saraiva, 2013.

SALGADO. Gisele Mascarelli. A Crítica do Direito pela Literatura: A partir da obra de Kafka e Philip Dick. Disponivel em: <http://www.ambitojuridico.com.br/site/?n_link=revista_artigos_leitura\&artigo_id=11717\#_ftn10> Acesso em: 09 mar. 2015.

SCHNAID, David. Filosofia do Direito e Interpretação. Londrina: UEL, 1998. 